\title{
STOP 2: Late-glacial and postglacial environmental changes, Lake Āraiši, Vidzeme Upland
}

\section{Normunds Stivriņ̌s}

Tallinn University of Technology, Estonia

Palaeoecological records preserved in sedimentary deposits can provide a unique insight into the nature of past ecosystems. Moreover, the rapid fluctuations in climate and environmental conditions during the Late Glacial make this time period an important focus of study (Lowe et al. 1999). Relatively small, closed lakes are sensitive to these changes and integrate information about such variations in the lake basin and its catchment (Seppä et al. 2009). Although studies on the Late Glacial in the eastern Baltic area go back more than a century, focussing on ice-recession lines and chronology (Kalm 2012; Zelčs and Markots 2004; Zelčs et al. 2011), there is a lack of studies based on lake sediments. Thus, uncertainty remains with respect to the relative timing of environmental changes in relation to climatic fluctuation during the Late Glacial.

Lake Âraiši is located $\left(57^{\circ} 15^{\prime} \mathrm{N}, 25^{\circ} 17^{\prime}\right.$ E) in central Latvia (Fig. 2.1), on the northwestern edge of the Vidzeme Upland, $6 \mathrm{~km} \mathrm{~S}$ of the town of Cēsis, at an elevation of $120.2 \mathrm{~m}$ a.s.l. The lake covers 32.6 ha, with a flow-through hydrological regime. It has a mean and maximum depth of 4 and $12.3 \mathrm{~m}$, respectively. The size of the lake's catchment area is $\sim 10 \mathrm{~km}^{2}$. The surrounding undulating landscape consists predominantly of open fields and meadows.

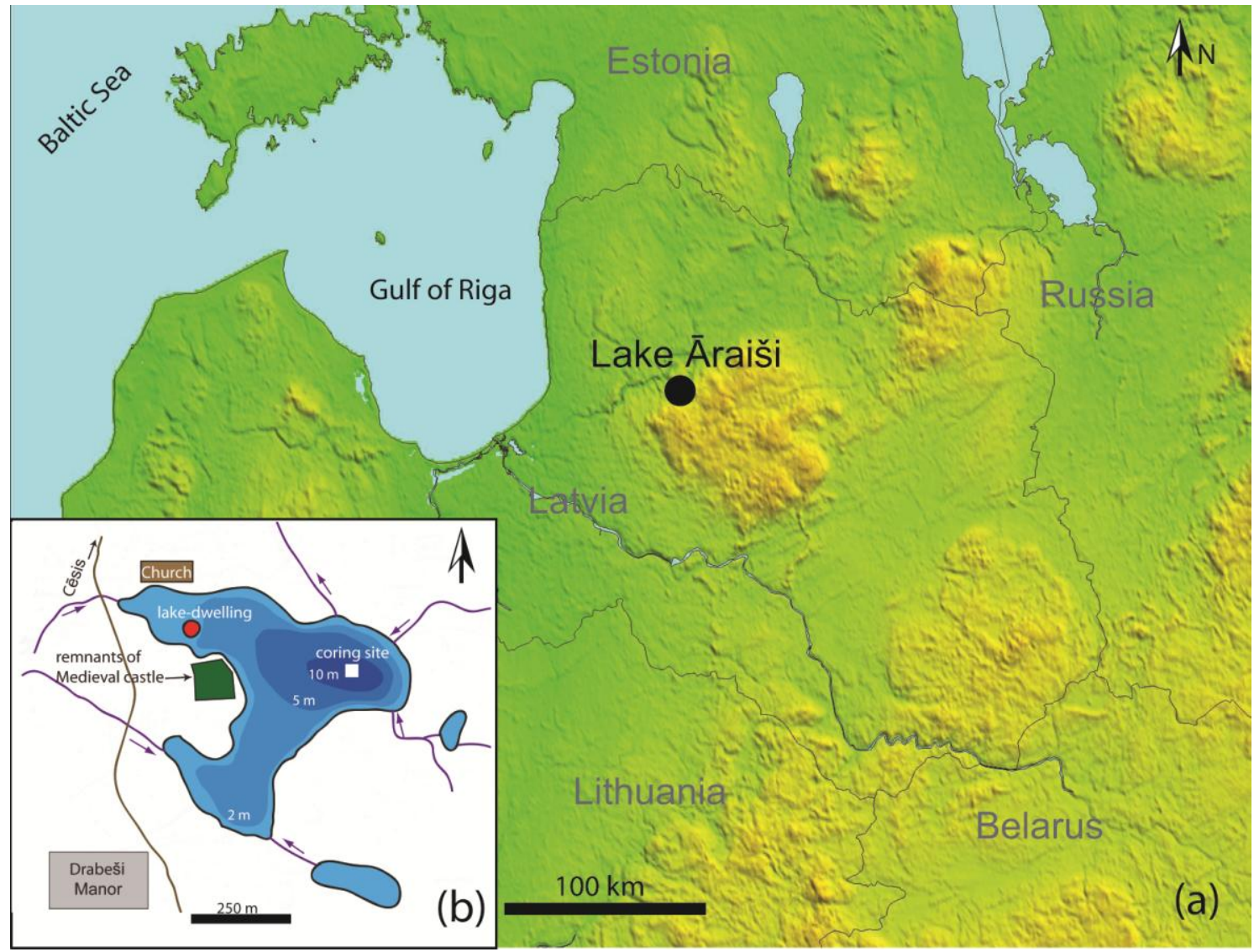

Fig. 2.1. The study area: (a) location of Lake Āraiši; (b) coring site and setting of the lake.

The present-day topography was largely formed during the Late Weichselian glaciation and deglaciation (Zelčs and Markots 2004; Zelčs et al. 2011). In the Lake Āraiši area the 
bedrock surface of Devonian siliciclastic sedimentary rock is overlain by $80 \mathrm{~m}$ of glacial deposits. Although the site is located in the continental-maritime transitional zone, the climate may be characterized as moderately continental. The mean annual precipitation is $700-800$ $\mathrm{mm}$, with mean temperatures in January and July of $-6^{\circ} \mathrm{C}$ and $+16.5^{\circ} \mathrm{C}$, respectively.

Coring for laboratory analyses was undertaken using a 1-m-long Russian-type corer, a 12.4-m-long sediment sequence being recovered at the deepest point of the lake $(12.3 \mathrm{~m})$ from the ice-covered surface in March 2012 (See Fig. 2.1 (b) for location). Sediment cores were documented and packed in film-wrapped 1-m plastic PVC semi-tubes. Loss on ignition (LOI) analysis was performed at 2-cm continuous intervals. Samples were dried overnight at $105^{\circ} \mathrm{C}$, combusted at $550^{\circ} \mathrm{C}$ for 4 hours to determine the organic matter $(\mathrm{OM})$ content of the sediment and the ignition residue was estimated as the mineral matter (MM) content of the sediment. Magnetic susceptibility (MS) was measured with a Bartington MS2E meter (Nowaczyk 2001). In addition, pollen and non-pollen palynomorphs were identified. For the purpose of cryptotephra (distal tephra) investigation, sampling for rhyolitic glass shard extraction was carried out as described by Turney (1998) and Blockley et al. (2005). Rangefinder samples were taken at 5-cm intervals. After removal of OM, the samples were sieved, and particles between 25 and $80 \mu \mathrm{m}$ were centrifuged in sodium polytungstate (SPT) to float rhyolitic shards from the background mineral matrix. Shards were identified optically under a polarizing light microscope.

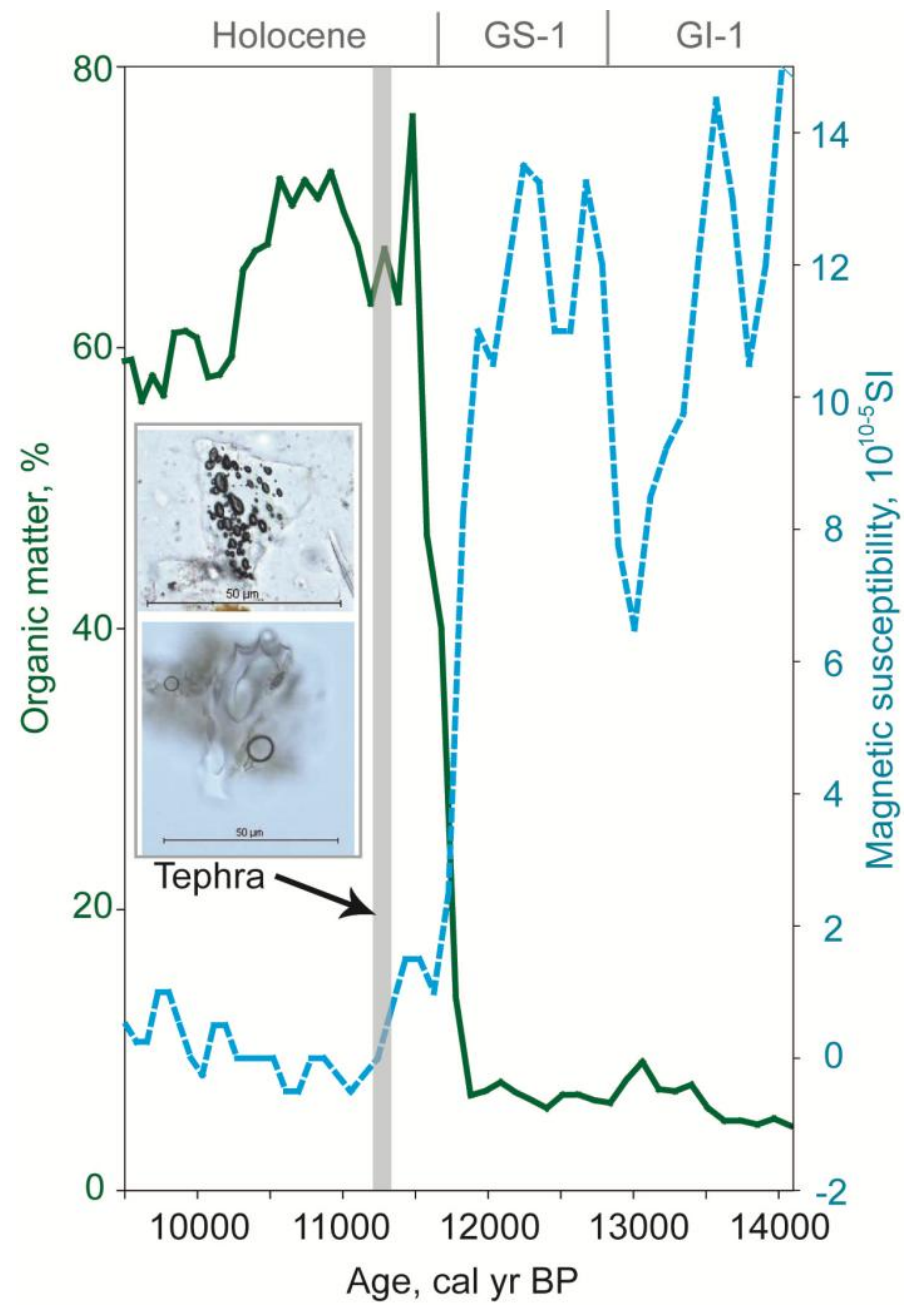

Fig. 2.2. Organic matter and magnetic susceptibility for Late Glacial sequence from Lake Āraiši. Grey vertical line indicates location of microtephra horizon; two pictures of microtephra are given at left. 
The chronology for the whole sequence was based on $12{ }^{14} \mathrm{C}$ conventional and five ${ }^{14} \mathrm{C}$ AMS dates, and the chronology of the upper part on the distribution of spheroidal fly-ash particles (Rose et al. 1990; Heinsalu and Alliksaar 2009). Samples were dated at the Institute of Geology at the Tallinn University of Technology (Tln) in Estonia and Poznan Radiocarbon Laboratory (Poz) in Poland.

The results revealed that the Lake Āraiši depression was ice-free at least by $14,100 \mathrm{cal}$ yr BP. In addition, macrofossil finds suggest the development of vegetation in the surroundings and the start of $\mathrm{OM}$ accumulation in Lake Âraiši from that time onwards (Fig. 2.2). These dates show good agreement with results of regional studies (Amon et al. 2014; Veski et al. 2012) and support the idea of relatively rapid ice retreat from the eastern Baltic. Moderately higher OM and lower MS values indicate changes in vicinity corresponding to the warmer period (Allerød) (Lowe et al. 2008) at the end of GI-1 (Fig. 2.2). Following cooling at GS-1 (Younger Dryas) there was increased inwash of MM into the lake, as also indicated by the elevated MS. Rapid accumulation of $\mathrm{OM}$ at the Pleistocene-Holocene boundary indicates major changes in the surroundings of Lake Āraiši. In a study on Lake Lielais Svētini (eastern Latvia) Veski et al. (2012) reported an accumulation of OM-rich gyttja and forest re-expansion at the start of the Holocene warming.

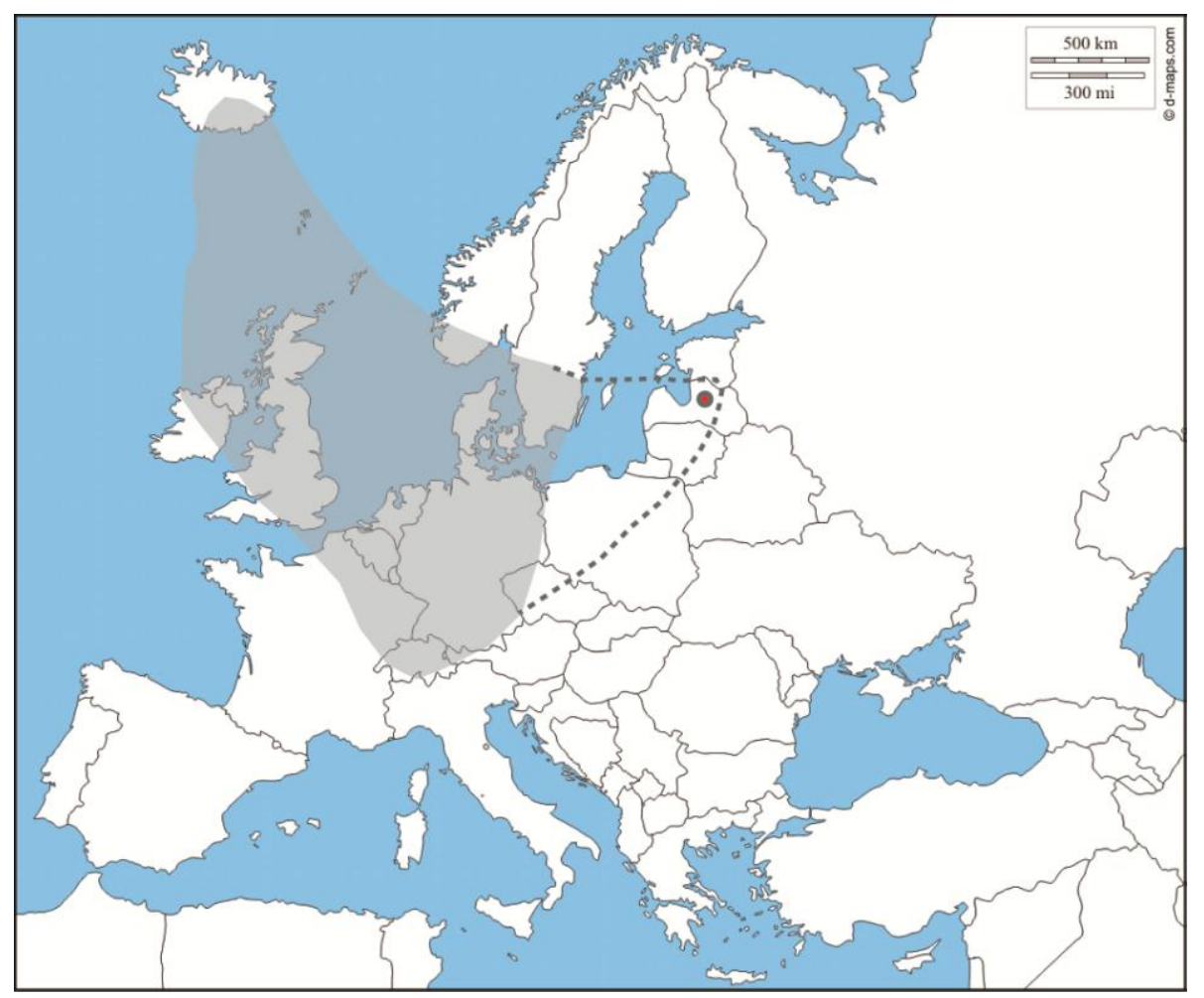

Fig. 2.3. Tephrostratigraphic time-slice map showing the currently known distribution of fallout deposits of the Hässeldalen and Askja tephras. Map redrawn after Lane et al. (2012). Grey shaded area - dispersal envelope of tephra layers; dotted line - possible dispersal of tephra; circle - location of Lake Āraiši.

Furthermore, the finds of microtephra shards (Fig. 2.3) at a depth of 23.40-23.45 m $(11,050-11,300$ cal yr BP) could be used as a time-marker horizon in future. However, a greater concentration of shards should be obtained and geochemical analyses performed. The Hässeldalen tephra $(11,360-11,300 \mathrm{cal}$ yr BP) is the possible source for this tephra. Lilja et al. (2013) point out that, due to several eruptive events and stratigraphical proximity, the 10-ka Askja could be another possible source. Even though there are two possible sources, this discovery offers great potential as a regional isochrone, which could be used to synchronize the chronology and sediment records of the central and northern European deglaciation. 
The vicinity of Lake Āraiši was forested and sparsely populated, and the first cereal pollen grains showing human presence appear only at AD 400. During the Migration Period (AD 400-800) new tribal groups may have invaded, building the fortified lake-dwelling in A.D. 780 (Meadows and Zunde in press), associated with the most significant changes in landscape during the last 2000 years. The lake-dwelling was inhabited by Late Iron Age Latgallian tribes. During the early $13^{\text {th }}$ century, the Latgallian territory was conquered by the Order of Swordbrothers (the later Livonian Branch of the Teutonic Order), and the lakedwelling was destroyed. Nowadays the lake dwelling has been reconstructed and serves as an archaeological open-air museum.

\section{References}

Amon, L., Veski, S., Vassiljev, J. 2014. Tree taxa immigration to the eastern Baltic region, southeastern sector of Scandinavian glaciation during the Late-glacial period (14,500-11,700 cal. B.P.). Vegetation History and Archaeobotany, 23, 207-216.

Blockley, S.P.E., Pyne-O’Donnell, S. D.F., Lowe, J.J., Matthews, I.P., Stone, A., Pollard, A.M., Turney, C.S.M., Molyneux, E.G. 2005. A new and less destructive laboratory procedure for the physical separation of distal glass tephra shards from sediments. Quaternary Science Reviews, 24, 1952-1960.

Heinsalu, A., Alliksaar, T. 2009. Palaeolimnological assessment of environmental change over the last two centuries in oligotrophic Lake Nohipalu Valgjärv, southern Estonia. Estonian Journal of Earth Sciences, $58,124-132$.

Kalm, V. 2012. Ice-flow pattern and extent of the last Scandinavian Ice Sheet southeast of the Baltic Sea. Quaternary Science Reviews, 44, 51-59.

Lane, C.S., De Klerk, P., Cullen, V.L. 2012. A tephrochronology for the Lateglacial palynological record of the Endinger Bruch (Vorpommern, northe-east Germany). Journal of Quaternary Science, 27, 141-149.

Lilja, C., Lind, E.M., Morén, B., Wastegård, S. 2013. A Lateglacial-early Holocene tephrochronology for SW Sweden. Boreas, 42, 544-554.

Lowe, J. J., Birks, H. H., Brooks, S. J., Coope, G. R., Harkness, D. D., Mayle, F. E., Sheldrick, C., Turney, C.S.M., Walker, M.J. 1999. The chronology of palaeoenvironmental changes during the last glacialHolocene transition; towards an event stratigraphy for the British Isles. Journal of the Geological Society of London, 156, 397-410.

Lowe, J.J., Rasmussen, S.O., Bjorck, S., Hoek, W.Z., Steffensen, J.P., Walker, M.J.C., Yu, Z.C., INTIMATE Group. 2008. Synchronisation of palaeoenvironmental events in the North Atlantic region during the Last Termination: a revised protocol recommended by the INTIMATE group. Quaternary Science Reviews, $27,6-17$

Meadows, J., Zunde, M. in press. A lake-fortress, a floating chronology, and an atmospheric anomaly: the surprising results of a radiocarbon wiggle-match from Äraiši, Latvia. Geochronometria, xx-xx.

Nowaczyk, N.R. 2001. Logging of magnetic susceptibility. In: Smol, J.P., Last, W.M. (eds),Tracking Basin Analysis, Coring and Chronological Techniques. Environmental Change Using Lake Sediments, 1. Kluwer Academic Publishers, Dordrecht, pp. 155-170.

Rose, N.L. 1990. A method for the selective removal of inorganic ash particles from lake sediments. Journal of Paleolimnology, 4, 61-68.

Seppä, H., Bjune, A.E., Telford, R.J., Birks, H.J.B., Veski, S. 2009. Last nine-thousand years of temperature variability in Northern Europe. Climate of the Past, 5, 523-535.

Turney, C.S.M. 1998. Extraction of rhyolitic component of Vedde microtephra from minerogenic lake sediments. Journal of Paleolimnology, 19, 199-206.

Veski, S., Amon, L., Heinsalu, A., Reitalu, T., Saarse, L., Stivrins, N., Vassiljev, J. 2012. Lateglacial vegetation dynamics in the eastern Baltic region between 14,500 and 11,400 cal yr BP: A complete record since the B $\varnothing$ lling (GI-1e) to the Holocene. Quaternary Science Reviews, 40, $39-53$.

Zelčs, V., Markots, A. 2004. Deglaciation history of Latvia. In: Ehlers, J., Gibbard, P.L. (eds), Quaternary glaciations - extent and chronology of glaciations, part I: Europe. Developments in Quaternary Science, 2. Elsevier, Rotterdam, pp. 225-244.

Zelčs, V., Markots, A., Nartišs, M., Saks, T. 2011: Chapter 18: Pleistocene Glaciations in Latvia. In: Ehlers, J., Gibbard, P.L., Hughes, P.D. (eds.), Quaternary glaciations - extent and chronology. A closer look. Developments in Quaternary Sciences, 15. Elsevier, pp. 221-229. 

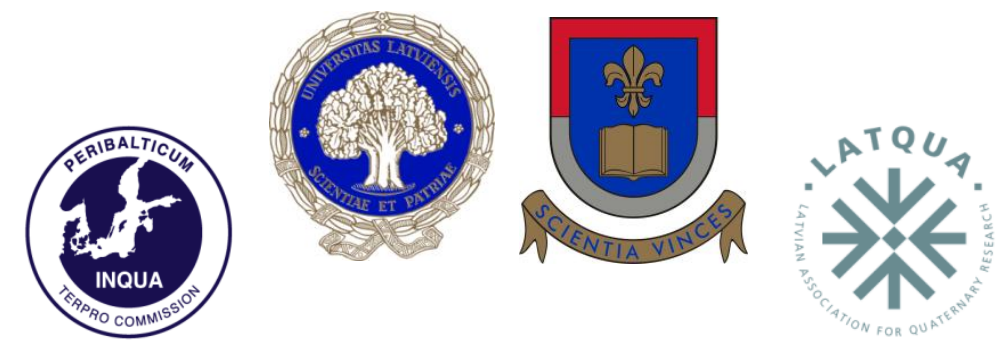

INQUA TERPRO COMMISSION PERIBALTIC WORKING GROUP

UNIVERSITY OF LATVIA

UNIVERSITY OF DAUGAVPILS

LATVIAN ASSOCIATION FOR QUATERNARY RESEARCH

\section{LATE QUATERNARY \\ TERRESTRIAL PROCESSES, SEDIMENTS AND HISTORY: FROM GLACIAL TO POSTGLACIAL ENVIRONMENTS}

EASTERN AND CENTRAL LATVIA

AUGUST 17-22, 2014 


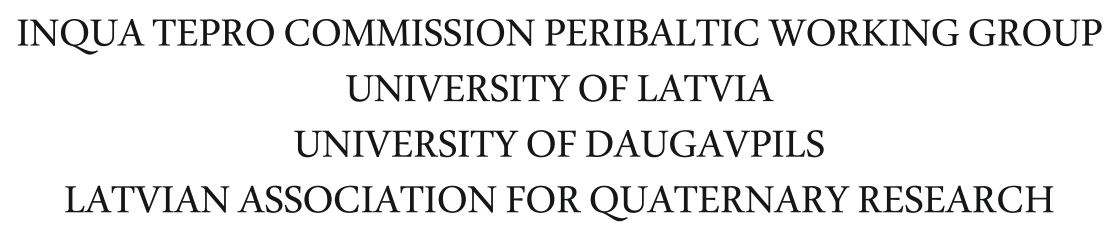

\title{
LATE QUATERNARY \\ TERRESTRIAL PROCESSES, SEDIMENTS AND HISTORY: FROM GLACIAL TO POSTGLACIAL ENVIRONMENTS
}

\author{
EASTERN AND CENTRAL LATVIA
}

AUGUST 16-22, 2014 
Organized by:

University of Latvia

Daugavpils University

Latvian Association for Quaternary Research

INQUA Peribaltic Working Group (INQUA TERPRO Commission)

Organizing committee:

Māris Nartišs (Chair, University of Latvia)

Māris Krievāns (Secretary, University of Latvia)

Aivars Markots (University of Latvia)

Juris Soms (Daugavpils University)

Evija Tērauda (University of Latvia)

Vitālijs Zelčs (University of Latvia)

Contributors:

Ivars Celiņš, Edgars Greiškalns, Ieva Grudzinska, Edyta Kalińska-Nartiša, Laimdota Kalniņa, Jānis Karušs, Māris Krievāns, Kristaps Lamsters, Aivars Markots, Māris Nartišs, Agnis Rečs, Normunds Stivriņš, Juris Soms, Ivars Strautnieks, Santa Strode, Sandra Zeimule, Vitālijs Zelčs

Editors: Vitālijs Zelčs and Māris Nartišs

The English texts of the field guide were revised by Valdis Bērziņš

Recommended reference for this publication:

Zelčs, V. and Nartišs, M. (eds.) 2014. Late Quaternary terrestrial processes, sediments and history: from glacial to postglacial environments. Excursion guide and abstracts of the INQUA Peribaltic Working Group Meeting and field excursion in Eastern and Central Latvia, August 17-22, 2014. University of Latvia, Rīga, 2014, 150 pages.

Sponsored by:

University of Latvia

Layout: Vitālijs Zelčs, Māris Nartišs and Māris Krievāns

ISBN 078-9934-517-60-0

(C) University of Latvia, 2014

This volume is available from:

Faculty of Geography and Earth Sciences

University of Latvia

Rainis Blvd. 19

Rìga, LV1586

Latvia 